\title{
EDUCAÇÃO CIENTÍFICA COMO ABORDAGEM PEDAGÓGICA E INVESTIGATIVA DE RESISTÊNCIA
}

\author{
SCIENTIFIC EDUCATION AS A PEDAGOGICAL AND \\ INVESTIGATIVE APPROACH OF RESISTANCE
}

\section{Wagner Rodrigues Silva*}

\section{RESUMO}

Este artigo apresenta uma releitura da abordagem da educação científica originária do campo de estudos do Ensino de Ciências. Foi proposto para ajustar a referida abordagem (a) a práticas de pesquisa nos estudos linguísticos aplicados e (b) ao ensino e formação de professores de língua materna. Este trabalho se configura num estudo bibliográfico ilustrado por alguns excertos documentais, e fundamenta-se em estudos do letramento, além de dialogar com outros referenciais teóricos de diferentes origens. A releitura reforçou a necessidade de readequação de funções tradicionalmente desempenhadas por alguns elementos integrantes das práticas de pesquisa e de ensino. Os encaminhamentos apresentados podem garantir investigações científicas mais democráticas e culturalmente sensíveis, além de uma abordagem pedagógica crítica, desencadeadora de práticas reflexivas em aulas de língua.

Palavras-chave: competências; ensino de língua; letramento científico.

\section{ABSTRACT}

This article presents a rereading of the approach to scientific education from the field of Science Teaching. It has been proposed to adjust that approach (a) to research practices in applied linguistics studies and (b) to the teaching of mother language and training of teachers. This work is configured in a bibliographical study illustrated by some documentary excerpts. It is based on studies of literacy, in addition to dialoguing with other theoretical references from different origins. The rereading reinforced the need for readjustment of functions traditionally performed by some elements of research and teaching practices. The referrals presented can guarantee more democratic and culturally sensitive scientific investigations, as well as a critical pedagogical approach, triggering reflective practices in language classes.

Keywords: competences; language teaching; scientific literacy.

O público percebe com mais clareza, portanto, que é através do programa das escolas que a ciência avançará e os ideais de um mundo livre se perpetuarão (HURD, 1958, p. 16)

\footnotetext{
* Universidade Federal do Tocantins - UFT, Palmas, TO, Brasil. wagnerodriguesilva@gmail.com Orcid: https://orcid.org/0000-0002-3994-1225

O autor deste artigo agradece ao Conselho Nacional de Desenvolvimento Científico e Tecnológico $(\mathrm{CNPq})$ pelo financiamento das pesquisas que possibilitaram a produção deste estudo (305094/2016-5; 304186/2019-8; 441194/2019-2).
} 


\section{INTRODUÇÃO}

A epígrafe deste artigo corresponde à segunda parte da resposta apresentada por Paul DeHart Hurd para uma pergunta por ele mesmo realizada para concluir um texto inaugural em torno do fenômeno então denominado de Science Literacy, o que, atualmente, no contexto brasileiro, tem-se oscilado entre as denominações alfabetização científica e letramento científico ${ }^{1}$. Num contexto pós-segunda guerra mundial (1939-1945) e de preparação para a exploração estadunidense do espaço (1969), daí os usos dos termos era científica (scientific age) e era espacial (space age) para caracterizar o período em propulsão, a pergunta compartilhada fora "Em que os satélites, foguetes e mísseis contribuíram para a educação americana?"2. Na primeira parte da resposta, Hurd (1958, p. 16) afirma que "eles criaram uma consciência da importância da ciência e tecnologia para o progresso social e segurança econômica". Tais produtos tecnológicos contribuíram para a propagação do sentimento de nacionalismo, compreendeu-se que o poderio da nação também poderia ser garantido por investimentos nas ciências.

Mais de cinco décadas após a publicação do texto inaugural de Paul DeHart Hurd em 1958, Xiufeng Liu, também no contexto estadunidense, destaca que, no final do século XX e início do século XXI, foi registrado um desenvolvimento econômico sem precedente devido a avanços na tecnologia e na globalização. Por essa razão, o desenvolvimento econômico da nação se tornou "dependente dos avanços da ciência e da tecnologia, criando demanda por trabalhadores técnicos e uma população cientificamente educada" (LIU, 2009, p. 301). A consistente formação profissional se tornou imprescindível para a produção de inovação e manutenção do desenvolvimento industrial diante de disputadas econômicas mundiais. Esse cenário realçou a demanda por uma reforma na educação científica não apenas nos Estados Unidos, mas também em outros países, a exemplo do Canadá e Inglaterra, conforme destacado por Liu (2009) ${ }^{3}$.

1. Uma versão preliminar deste artigo foi apresentada como conferência de encerramento da 13th International Free Linguistics Conference, na Universidade Federal da Paraíba (UFPB), e no Encontro Anual do ProfLetras, na Universidade Federal de Santa Catarina (UFSC), ambos em 2019. Foi apresentada ainda como aula inaugural do ano letivo de 2019, no Programa de PósGraduação em Linguagem e Ensino, da Universidade Federal de Campina Grande (UFCG).

2. As traduções de citações diretas para o português foram realizadas livremente pelo autor deste artigo.

3. Robinson e Aronica (2019, p. 17) afirmam que a educação é um tema político importante por razões culturais, sociais, pessoais e econômicos. Sobre o último aspecto, é dito que "nos últimos 25 anos, o comércio foi transformado pelos rápidos avanços da tecnologia digital e pelo crescimento populacional massivo. Nesse processo, a competição econômica intensificou o comércio, a produção de mercadorias e os serviços. Os governos sabem que uma força de trabalho educada é crucial para a prosperidade econômica nacional, e suas políticas estão salpicadas de retórica sobre termos como inovação, empreendedorismo e babilidades do século XXI. É por isso que eles investem tanto na educação e que ela é um dos maiores negócios do mundo" (itálico do original). 
Diferentemente das nações consideradas desenvolvidas que, dentre inúmeros outros investimentos, recorreram à educação científica da população em função do fortalecimento do desenvolvimento econômico, da segurança nacional e da qualificação da força de trabalho, o atual governo brasileiro eleito decidiu caminhar na contramão da história, ignorando os esforços acertados por outras nações ${ }^{4}$. Conforme defendido neste artigo, investimentos educativos desse tipo também precisam se caracterizar pelo comprometimento com demandas ou necessidades sociais diversas, valorizando saberes igualmente diversos. No Brasil, a economia foi utilizada, diferentemente, como justificativa explícita para contingenciar investimentos nas áreas de ciência e de educação, em resposta à necessidade vociferada de ajuste fiscal, que, de alguma forma, atinge outras áreas de atuação governamental sob o comando de diferentes ministérios.

Além do propagado ajuste fiscal, a comunidade científica brasileira padece com algumas atitudes governamentais ofensivas a práticas características do ofício de pesquisador, o que pode ser assimilado e reproduzido por parte da população desinformada sobre o assunto ${ }^{5}$. Essa toada pode fragilizar as representações compartilhadas por cidadãos comuns sobre as ciências e as práticas desenvolvidas pela referida comunidade, que precisa do apoio populacional esclarecido para ganhar visibilidade perante os políticos eleitos como representantes do povo.

Diante desse cenário, a inércia dos especialistas dificulta a reversão da situação, podendo a Linguística Aplicada (LA) reagir a partir de estudos do

4. Aqui faz-se referência ao presidente eleito e empossado com equipe montada para gestão quadrienal iniciada em 2019.

5. Mencionam-se dois principais casos para ilustrar o inconformismo governamental no tocante a resultados de pesquisas científicas que não colaboraram com as políticas públicas por eles defendidas. Desde 2017, a divulgação de uma pesquisa sobre consumo de drogas, financiada pelo governo federal e realizada pela Fundação Oswaldo Cruz (Fiocruz), considerada uma das principais instituições mundiais de pesquisa em saúde pública, foi embargada pelo Ministério da Justiça, que questionou o resultado produzido e a metodologia utilizada pelos especialistas. Observou-se que "as conclusões do estudo desmentiam o discurso do governo de que há uma epidemia no uso de crack no Brasil" (Fonte: https://exame.com/brasil/estudo-sobre-uso-de-drogas-e-liberado-aposmeses-de-censura-pelo-governo/. Acesso em 18 out. 2020). O segundo caso corresponde ao inconformismo do presidente brasileiro, Jair Messias Bolsonaro, no tocante aos dados reveladores do aumento das queimadas na Floresta Amazônica, divulgados pelo renomado Instituto Nacional de Pesquisas Espaciais (INPE). Instaurou-se um conflito entre o referido presidente e o então diretor do INPE, Ricardo Magnus Osorio Galvão, conforme observável nos seguintes enunciados respectivamente proferidos: "A questão do Inpe, eu tenho a convicção que os dados são mentirosos, e nós vamos chamar aqui o presidente do Inpe para conversar sobre isso, e ponto final nessa questão"; "ele me acusa de estar a serviço de uma ONG internacional. Ele já disse que os dados do Inpe não estavam corretos segundo a avaliação dele, como se ele tivesse qualidade ou qualificação de fazer análise de dados" (https://g1.globo.com/sp/vale-do-paraiba-regiao/noticia/2019/07/20/diretor-doinpe-nega-acusacoes-de-bolsonaro-reafirma-dados-sobre-desmatamento-e-diz-que-nao-deixaracargo.ghtml. Acesso em 18 out. 2020). 
letramento. Assim, apresenta-se uma releitura de contribuições vanguardistas sobre educação científica, elaboradas no Ensino de Ciências. Pontuam-se ainda algumas contribuições teórico-práticas para uma abordagem diferenciada da educação científica a fim de promover perspectivas investigativas e pedagógicas de resistência. Conforme Rajagopalan (2002, p. 204), a atitude política de resistência corresponde à articulação contra

\begin{abstract}
forças coercitivas que, num dado momento histórico, estejam atuando sobre um sujeito, acuando-o de forma cerrada com intuito de sufocá-lo, esmagá-lo ou, no mínimo, domesticálo ou neutralizá-lo. Isto é, a resistência é sempre resistência a algo, via de regra uma força opressora poderosa demais para ser repelida de uma só vez. Isto quer dizer que onde há resistência, há também forças de opressão - ou seja, a presença de resistência pressupõe a existência de forças de opressão.
\end{abstract}

O enfoque deste artigo se restringe à área de ensino de língua e formação de professores, mas contribuições para outras áreas podem ser apreendidas. Trata-se de uma pesquisa bibliográfica em que são estabelecidos diálogos, preponderantemente, com estudos favoráveis ao emprego da pesquisa como estratégia constitutiva do trabalho do professor e da formação discente na escola básica, e à mobilização democrática de saberes especializados ou não. Para tanto, são utilizados alguns excertos documentais como evidências ilustrativas de algumas questões teóricopráticas problematizadas. Este estudo se caracteriza como uma atitude de resistência diante das afrontas sofridas pela comunidade científica brasileira, pois não se compartilha a disposição para "se entregar sem luta, nem a se curvar diante do desafio de forma pacífica" (RAJAGOPALAN, 2002, p. 203) .

Este artigo está organizado em três principais seções, além desta introdução, das considerações finais e das referências. Na primeira, são sistematizados e confrontados alguns aspectos teóricos caraterizadores da educação científica conforme literatura selecionada no campo de estudos vanguardista no assunto - Ensino de Ciências. $\mathrm{Na}$ segunda, é apresentada uma releitura de categorias teóricas configuradoras da abordagem diferenciada da educação científica para os estudos linguísticos aplicados, destacando ganhos daí originários. Na terceira, finalmente, são compartilhados os fundamentos teóricos propostos e passíveis de apropriação para o ensino de língua informado por uma abordagem diferenciada da educação científica.

6. Ainda nos termos de Rajagopalan (2002, p. 204), "a resistência tem como motor propulsor o que há de mais nobre do ser humano - a vontade, a determinação, de não se curvar diante do desafio, de crescer à altura das forças que se colocaram no seu caminho. [...] Quem oferece resistência é um sujeito, valendo-se de sua condição enquanto agente da sua própria ação". 


\section{0 QUE DIZ A LITERATURA SOBRE A EDUCAÇÃO CIENTÍFICA?}

No campo do Ensino de Ciências, são utilizadas distintas nomenclaturas para nomear o fenômeno focalizado na abordagem da educação científica. $\mathrm{Na}$ literatura estrangeira, além do termo Science Literacy, encontra-se o Scientific Literacy (HOLBROOK; RANNIKMAE, 2009; HURD, 1998; 1958; LIU, 2009). No Brasil, as nomenclaturas oscilam entre alfabetização científica e letramento científico, o que, a princípio, poderia se justificar pela imprecisão tradutória para o português, que disponibiliza as palavras alfabetização e letramento como possibilidades, mesmo que, do ponto de vista teórico, seja possível considerar algumas especificidades (CHASSOT, 2014; DEMO, 2010; SANTOS, 2007; SASSERON; CARVALHO, 2008; SILVA, 2019a $)^{7}$.

Utilizando-se da nomenclatura Science Literacy, Hurd (1958) salienta que os educadores eram questionados por realizarem os mesmos cursos com alunos diferentes, utilizando-se dos mesmos materiais, metodologias e tempo de aula, ignorando-se as habilidades diferenciadas dos alunos identificados como "brilhantes", ou seja, que, mesmo na escola básica, já demonstravam talentos para as ciências naturais. $\mathrm{O}$ ensino de ciências naturais ainda parecia desinteressante para os alunos por não perceberem aplicabilidade dos conteúdos trabalhados em aula. Van Aalsvoort (2004a) afirma que, devido a uma lógica positivista de ensino, a qual, dentre outros aspectos caracterizadores, "constrói uma divisão entre a ciência, por um lado, e a tecnologia e a sociedade, por outro" (p. 1158), "os alunos veem a ciência como trabalho escolar ou uma matéria escolar, não como uma maneira de entender suas próprias experiências" (p. 1152).

A nomenclatura Scientific Literacy é utilizada por Hurd (1998) em estudo publicado quatro décadas depois da datação do texto inaugural sobre o assunto ${ }^{8}$. $\mathrm{O}$ autor elenca algumas transformações na configuração das ciências, a exemplo do fracionamento e hibridização das disciplinas resultando em inúmeros campos do conhecimento. Destaca a emergência de pesquisas estratégicas, produzidas a partir do diálogo entre diferentes disciplinas, em função do aprimoramento do "bem-estar humano, desenvolvimento econômico, progresso social e qualidade de vida" (HURD, 1998, p. 409). Assim, enfatizando a funcionalidade das ciências, define Scientific Literacy "como uma competência cívica necessária para o pensamento racional sobre a ciência

\footnotetext{
7. A possibilidade de imprecisão conceitual a partir da escolha lexical para traduzir os referidos termos para o português motivou a manutenção das versões em inglês quando feitas referências a literaturas estrangeiras neste artigo.

8. Destaca-se o título sugestivo atribuído ao artigo: "Letramento científico: novas mentes para um mundo em mudança" ("Scientific Literacy: New Minds for a Changing World").
} 
em relação a problemas pessoais, sociais, políticos, econômicos e questões que provavelmente se encontrará ao longo da vida". (HURD, 1998, p. 410).

A nomenclatura Scientific Literacy também é utilizada por Holbrook e Rannikmae (2009). Os autores apresentam dois pontos de vista assumidos na literatura especializada para o fenômeno focalizado, os quais revelam compreensões distintas. Pode-se enfatizar o conbecimento sobre ciências, portanto um indivíduo cientificamente letrado se apropriaria de "ideias fundamentais" e conteúdos privilegiados sobre ciências conforme legitimado por professores. Para os autores, essa compreensão pode ser denominada de Science Literacy, mesmo não sendo uma nomenclatura comum, parecendo ser um "jogo de palavras". Na segunda compreensão, enfatizase a utilidade social dos saberes sobre ciência, compreendendo habilidades e valores apropriados para a formação de cidadãos receptivos a situações influenciadas pelas ciências.

O primeiro ponto de vista revela a valorização de saberes e habilidades para serem utilizados na escola ou no domínio científico em função da interação dos aprendizes com professores ou pesquisadores, realiza-se uma iniciação científica mais restrita dos alunos. $\mathrm{O}$ segundo ponto de vista demanda uma atitude diferenciada dos aprendizes, pois, além de compartilhar os conhecimentos e habilidades pressupostas no primeiro, demanda-se alguma responsabilidade social. Assim, têm-se duas abordagens pedagógicas denominadas, respectivamente, por Holbrook e Rannikmae (2009) de ciência através da educação e educação através da ciência, as quais são caracterizadas a partir das habilidades descritas no Quadro 1 elaboradas pelos próprios autores.

A abordagem da educação através da ciência garantiria os atributos de desenvolvimento social, elencado por Holbrook e Rannikmae, (2009, p. 282) como um dos três elementos sustentadores do Scientific Literacy, juntamente aos atributos de desenvolvimento pessoal e à natureza da ciência. A observância desses elementos demanda um ensino contextualizado e pode garantir aplicabilidade ou funcionalidade aos objetos de conhecimento na vida cotidiana.

Nessa perspectiva, Van Aalsvoort (2004a, p. 1152; 2004b, p. 1635) elenca quatro significados identificadores de distintas relevâncias para as aulas de Química, em resposta à insatisfação manifestada por discentes com relação às aulas da referida disciplina: (i) relevância pessoal - "deve fazer conexões com a vida dos alunos"; (ii) relevância profissional - "deve mostrar aos alunos um quadro de possíveis profissões"; (iii) relevância social - "deve esclarecer o propósito da disciplina em problemas humanos e sociais"; (iv) relevância pessoal/social - "deve ajudar os alunos a se tornarem cidadãos comprometidos com questões delicadas atreladas a impactos provocados pela ciência". 


\section{Quadro 1. Abordagens do Scientific/Science Literacy}

\begin{tabular}{|l|l|}
\hline Ciência através da Educação & Educação através da Ciência \\
\hline $\begin{array}{l}\text { Aprender saberes, conceitos, teorias e leis } \\
\text { fundamentais de ciência. }\end{array}$ & $\begin{array}{l}\text { Aprender saberes e conceitos da ciência } \\
\text { importantes para compreender e lidar com } \\
\text { questões sociocientíficas na sociedade. }\end{array}$ \\
\hline $\begin{array}{l}\text { Realizar as atividades de ciência através de } \\
\text { questionamento de aprendizagem como parte } \\
\text { do desenvolvimento do aprendizado para ser um } \\
\text { cientista. }\end{array}$ & $\begin{array}{l}\text { Realizar solução de investigação de problema } \\
\text { científico para melhor compreender o } \\
\text { conhecimento de ciência relacionado a } \\
\text { questões sociocientíficas na sociedade. }\end{array}$ \\
\hline $\begin{array}{l}\text { Obter uma compreensão da natureza da ciência a } \\
\text { partir de um ponto de vista científico. }\end{array}$ & $\begin{array}{l}\text { Obter uma compreensão da natureza da ciência } \\
\text { a partir de um ponto de vista social. }\end{array}$ \\
\hline $\begin{array}{l}\text { Realizar trabalho prático e apreciaro trabalho dos } \\
\text { cientistas. }\end{array}$ & $\begin{array}{l}\text { Desenvolver habilidades pessoais relacionadas } \\
\text { à criatividade, iniciativa, trabalho seguro, etc. }\end{array}$ \\
\hline $\begin{array}{l}\text { Desenvolver atitudes positivas diante da ciência } \\
\text { e de cientistas. }\end{array}$ & $\begin{array}{l}\text { Desenvolver atitudes positivas diante da ciência } \\
\text { como principal elemento no desenvolvimento } \\
\text { da sociedade e em empreendimentos } \\
\text { científicos. }\end{array}$ \\
\hline $\begin{array}{l}\text { Adquirir habilidades comunicativas para formatos } \\
\text { orais, escritos e simbólicos/tabulares/gráficos } \\
\text { como parte do aprendizado sistemático de } \\
\text { ciência. }\end{array}$ & $\begin{array}{l}\text { Adquirirhabilidades comunicativas relacionadas } \\
\text { a formatos orais, escritos e simbólicos/ } \\
\text { tabulares/gráficos para melhor expressar ideias } \\
\text { científicas em um contexto social. }\end{array}$ \\
\hline $\begin{array}{l}\text { Realizar tomada de decisão diante de questões } \\
\text { científicas. }\end{array}$ & $\begin{array}{l}\text { Realizar tomada de decisão sociocientíficas } \\
\text { relacionadas a questões emergentes da } \\
\text { sociedade. }\end{array}$ \\
\hline $\begin{array}{l}\text { Aplicar os usos de ciência à sociedade e apreciar } \\
\text { questões éticas enfrentadas por cientistas. }\end{array}$ & $\begin{array}{l}\text { Desenvolver valores sociais para tornar-se } \\
\text { cidadão responsável e empreender carreiras } \\
\text { relacionadas à ciência. }\end{array}$ \\
\hline
\end{tabular}

Fonte: Holbrook e Rannikmae (2009, p. 283).

A abordagem identificada pelo termo Science Literacy, cuja ênfase recai sobre conteúdos privilegiados de ciências, conforme mencionado por Holbrook e Rannikmae (2009), não se confirma no estudo de Liu (2009), que, ao utilizar o referido termo, propõe uma abordagem crítica passível de ser caracterizada como culturalmente sensível, numa perspectiva semelhante a estudos críticos do letramento desenvolvidos no contexto brasileiro da LA (KLEIMAN; BORGES DA SILVA, 2008; SILVA, 2019b). Assim, Science Literacy é compreendido como

um processo estável e ao longo da vida, como uma escolha pessoal e uma necessidade econômica, e como um aprimoramento pessoal e participação cívica. Caracteriza a educação científica para além de práticas escolares, envolve todas as atividades que ocorrem dentro e fora das escolas, o que cria um potencial muito maior para o Science Literacy de todos os cidadãos. Essa noção ampliada de Science Literacy pode ser chamada de ciência e público. (LIU, 2009, p. 307) 
Essa compreensão é detalhada por Liu (2009) a partir de três fendas identificadas em estudos em torno do Science Literacy e descritas como tipos de modelo. São lacunas interconectadas que precisam ser evitadas em função da produção de interações mais harmoniosas e libertárias: modelos de déficit; modelo de mercadoria; e modelo estático. No primeiro, ignoram-se conhecimentos e experiências individuais sobre fenômenos naturais, apropriados por estudantes ou cidadãos comuns em situações informais do cotidiano. Por legitimar conhecimentos especializados, esse modelo "serve para manter o domínio de grupos de interesses especiais, como elites ou tecnocratas - aqueles com poder político e econômico, excluindo outros - especialmente minorias" (HURD, 1998, p. 306).

Nas escolas, a abordagem da educação científica, seja no ensino de Ciências Naturais ou no de língua materna, conforme proposto neste artigo, não pode ser utilizada para supervalorizar saberes e práticas dominadas por pesquisadores, ignorando produções locais, destacando-se, por exemplo, os coletivos de indígenas, quilombolas, ribeirinhos, pescadores ou quebradeiras de coco. Mesmo muitas vezes desconhecidos, os saberes desses grupos são concebidos por pessoas escolarizadas como folclore, crença ou mito ${ }^{9}$. A atitude assumida pela comunidade escolar diante do domínio científico está condicionada às concepções de ciências por ela compartilhada.

No segundo modelo, concebe-se o Science Literacy como um estado ou mercadoria a ser alcançada, não como um processo ao longo da vida com consequências pessoais e sociais práticas. Ignora-se, por exemplo, que mesmo um especialista em determinado campo do conhecimento pode desconhecer a ciência praticada em outro, bem como seus desdobramentos no cotidiano das pessoas, evidenciando a necessidade de um aprendizado constante em contextos formais e informais. A noção de processo se encontra subjacente a concepções de letramento convencional, conforme perspectivas analíticas mais complexas sobre o assunto $(\text { HASAN, 1996; SOARES, 2003) })^{10}$. No terceiro, reconhece-se um fluxo exclusivo

9. O termo coletivo foi empregado por influência da expressão "pessoas coletivas", utilizada pelo ativista ambiental indígena Ailton Krenak (2019, p. 28) para fazer referência a pessoas que "não são indivíduos, mas 'pessoas coletivas', células que conseguem transmitir através do tempo suas visões de mundo". A título de ilustração da rejeição aos saberes locais, reproduzimos o seguinte relato de Krenak (2019, p. 49): "Quando nós falamos que o nosso rio é sagrado, as pessoas dizem: 'Isso é algum folclore deles'; quando dizemos que a montanha está mostrando que vai chover e que esse dia vai ser um dia próspero, um dia bom, eles dizem: 'Não, uma montanha não fala nada'".

10. A esse respeito, Soares (2003) afirma que "do processo de alfabetização pode-se esperar que resulte, ao fim de determinado tempo de aprendizagem, em geral pré-fixado, um 'produto' que se pode reconhecer, cuja aquisição, ou não, atesta ou nega a eficiência do processo de escolarização; ao contrário, o processo de letramento jamais chega a um 'produto' final, é sempre e permanentemente um 'processo'". 
de informação, sempre partindo dos conhecedores ou sábios para os menos conhecedores ou menos sábios. Equivocadamente, o conhecimento científico é considerado universal ou livre de contexto, negando-se que as práticas científicas são construídas localmente, conforme cultura em que estão inseridas.

Liu (2009) destaca que os alunos também se apropriam de conhecimentos científicos fora da escola a todo tempo e de diversas maneiras, a exemplo de visitas a museus e do acesso a livros, revistas, jogos, brinquedos e filmes exibidos em diferentes mídias. Realça-se ainda os diversos ambientes virtuais disponibilizados a partir da democratização em curso dos serviços de internet. $\mathrm{O}$ autor propõe que a educação científica formal e informal sejam conectadas e consideradas num contínuo, cabendo aos professores, ao planejarem suas aulas, partirem dos conhecimentos sobre ciências apropriados livremente pelos alunos. $\mathrm{O}$ autor recomenda ainda que profissionais de diferentes áreas do conhecimento participem de atividades científicas e promovam a educação científica para o público comum com o qual interagem. Numa sociedade educada cientificamente, a resistência a discursos depreciativos em torno da ciência seria mais forte. Nas palavras de Liu (2009, p. 308):

Isso requer que todos os profissionais se tornem participantes da ciência e educadores. Os atuais programas de formação de professores de ciências educam apenas professores de ciências escolares; é necessário educar educadores de ciências fora da escola para cumprir a missão da ciência e do público. [...] os pesquisadores, embora possam estar bem preparados com os conhecimentos e habilidades atuais em ciências, podem não saber como comunicar a ciência ao público em geral.

Em pesquisa de mestrado na LA, Santana (2019), por exemplo, caracterizou o gênero desenho animado científico a partir da investigação da animação brasileira infantil O Show da Luna, disponível na internet e exibida na televisão por assinatura ${ }^{11}$. Conteúdos e práticas científicas em torno das ciências da natureza são ensinados explicitamente na referida animação. Assim, dentre outros resultados, a pesquisa mostrou a ausência de conteúdos atrelados às ciências humanas nos episódios das duas primeiras temporadas investigadas. Diante desse resultado, o autor produziu dois roteiros de episódios seguindo as convenções descritas do gênero, tematizando práticas investigativas no âmbito dos estudos linguísticos.

Na referida pesquisa, Santana (2019) também identificou a apropriação do desenho animado científico num projeto pedagógico desenvolvido por professoras brasileiras na Educação Infantil, assim como proposto por Liu (2009). O propósito

11. Endereço do canal oficial: https://www.youtube.com/channel/UC-adUJnjdrRnRlOJGoDtTqw. Acesso em 18 out. 2020. 
do projeto consistia na familiarização das crianças com práticas científicas, além de desenvolver simultaneamente outras competências. A etapa final do projeto foi a exposição da pesquisa pelas próprias crianças, realizada numa mostra científica, reunindo estudantes expositores da educação infantil ao ensino superior, promovida para o público em geral pela prefeitura municipal de Palmas, capital do Estado do Tocantins, localizado na Região Norte do Brasil ${ }^{12}$.

A abordagem da educação científica foi produzida como resposta a metodologias reprodutivistas de conteúdos escolares descontextualizados em aulas de Ciências Naturais, dentre outros fatores descritos nesta seção. Para tanto, a partir de pesquisas desenvolvidas, procura-se garantir "a construção de benefícios práticos para as pessoas, a sociedade e o meio-ambiente" (SASSERON, CARVALHO, 2008, p. 334). Informada pela tradição escolar, prática reprodutivista semelhante se observa em outros componentes curriculares, a exemplo das aulas de Português no território brasileiro. Na seção seguinte, compartilha-se uma releitura de pressupostos teóricos da educação científica para informar abordagens investigativas e pedagógicas em aulas do referido componente curricular.

\section{QUAL É O LUGAR DA EDUCAÇÃO CIENTÍFICA NA LA?}

$\mathrm{Na}$ literatura especializada, encontram-se diferenças conceptuais a respeito da alfabetização e do letramento, especialmente quando se considera estudos publicados em diferentes momentos (FREIRE, 2011; KLEIMAN, 1995; NASCIMENTO, 1998; SOARES, 2003; SILVA, 2019a). No contexto brasileiro, já se construiu algum consenso sobre a necessidade desses termos para nomear processos distintos e complementares (SOARES, 2003; 2004; SILVA, 2009a). Assim, a alfabetização corresponde ao processo de conhecimento do sistema de escrita prioritariamente nos primeiros anos escolares, resultando no aprendizado da leitura e da escrita. O letramento são habilidades de uso da escrita conforme demandado em diferentes domínios sociais, a exemplo do artístico, comercial, jornalístico e religioso, além do próprio domínio escolar.

A diferenciação desses fenômenos se justificou pelo fracasso escolar ao não garantir que o conhecimento linguístico trabalhado possibilitasse que os alunos exercessem práticas de leitura e escrita conforme demandado em contextos interativos diversos. Alguns alunos leem, mas têm dificuldade ou, até mesmo, não

12. O evento denomina-se Feira de Empreendedorismo, Ciências, Inovação e Tecnologia do Tocantins (FECIT), realizada anualmente no segundo semestre letivo do calendário escolar. Para maiores detalhes sobre a FECIT, sugere-se a leitura de Fernandes (2016). 
compreendem o conteúdo do texto; produzem cópias, mas não redigem textos com autonomia. Na escola, focalizar esses processos distintos simultaneamente e com maior precisão significa uma aposta diante de resultados insatisfatórios.

A proposição de uma abordagem diferenciada da educação científica na LA demanda que as especificidades constitutivas da alfabetização e do letramento sejam consideradas. Nesta proposta pedagógica, a Alfabetização Científica e o Letramento Científico são concebidos como fenômenos diferentes e complementares, conforme representados na Figura 1. Essa distinção permite que pesquisadores e professores focalizem mais diretamente distintos aspectos constitutivos do processo de Educação Científica.

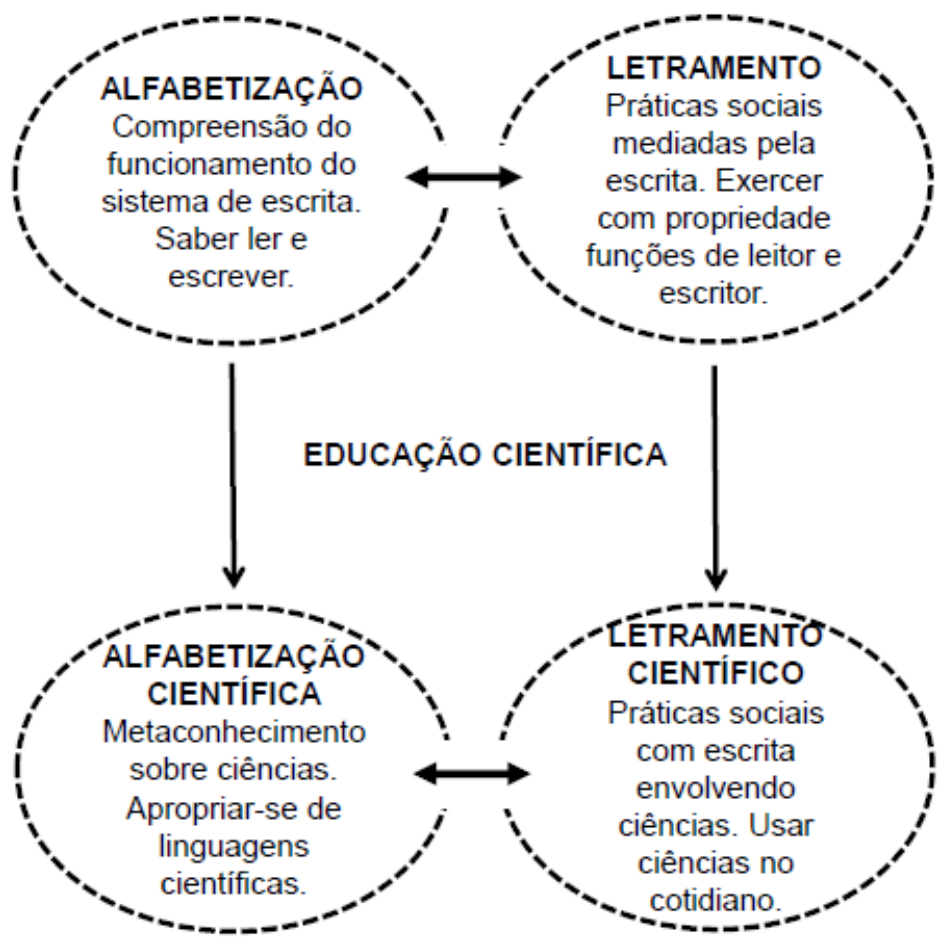

Figura 1. Configuração da Educação Científica Fonte: autoria própria

Nas séries mais avançadas, os professores de língua são desafiados a se distanciarem do exaustivo trabalho metalinguístico característico da tradição escolar, também marcado por exercícios desmotivadores de leitura e escrita. Esses e outros usos da escrita próprios da referida instituição compõem os letramentos escolares 
(SIGNORINI, 2007a; STREET; STREET, 1991), os quais precisam ser mediados pelos professores tomando como modelo ou referência práticas de escrita estabilizadas em outros domínios sociais ${ }^{13}$. Esse cenário se assemelha ao desafio enfrentado pelos professores das Ciências Naturais diante do desencantamento dos alunos com aulas padronizadas (cf. HURD, 1958; 1998; VAN AALSVOORT, 2004a; 2004b).

Quaisquer componentes curriculares (tradicionalmente conhecidos como disciplinas escolares) compartilham demandas para a inovação pedagógica e podem encontrar subsídios na abordagem da educação científica, afinal estão atrelados a algum campo do conhecimento. Na escola, o trabalho investigativo em componentes curriculares diferentes das Ciências Naturais pode ampliar noções de ciências compartilhadas pela comunidade local. Dificilmente haverá encaminhamentos diretos para o meio-ambiente, conforme constitutivo na abordagem original da educação científica (SASSERON $;$ CARVALHO, 2008), mas contribuições pessoais e sociais diferenciadas podem ser geradas.

No contexto adverso para a ciência brasileira, foi lançado pelo governo federal o Programa Ciência na Escola (PCE), uma iniciativa com perspectivas promissoras entre o Ministério da Educação (MEC) e o Ministério da Ciência, Tecnologia, Inovação e Comunicação (MCTIC). O programa objetiva desenvolver a educação científica dos alunos da segunda etapa do Ensino Fundamental e do Ensino Médio. Fora projetado a partir de quatro ações: Olimpíada Nacional de Ciências $(\mathrm{ONC})$; Ciência é 10 - Especialização à Distância em Ensino de Ciências; Chamada Pública para Instituições; e Chamada Pública para Pesquisadores. Ao navegar no portal do PCE ou acessar os documentos disponíveis, o leitor pode se perguntar se o programa foi idealizado para englobar todas as disciplinas escolares nas ações delineadas ou só algumas delas.

A ONC, por exemplo, é caracterizada como "um programa da Sociedade Brasileira de Física (SBF), Associação Brasileira de Química (ABQ), Instituto Butantã e Sociedade Astronômica Brasileira $(\mathrm{SAB})^{\prime \prime 14}$, contemplando na edição de

13. Conforme Signorini (2007a, p. 323), "o letramento escolar se constitui de práticas letradas específicas, no caso do ensino de Língua Portuguesa, essas são práticas orientadas para a comunicação social em sentido amplo (não só a comunicação no âmbito institucional) e para a objetivação de saberes sobre o funcionamento e os usos da língua nacional. São também práticas que estão em relação solidária e/ou de confronto com outras práticas sociais dentro e fora da instituição. Um exemplo significativo a esse respeito é o das práticas escolares de leitura/escrita em suas relações com as de outras esferas de grande influência na sociedade, como as instituições acadêmicas e jornalísticas, por exemplo; bem como outras práticas da mesma esfera, como as de gerenciamento escolar do uso de espaços extraclasse, como bibliotecas e salas de informática, por exemplo".

14. Fonte: <https://www.ciencianaescola.gov.br/app/ciencianaescola/olimpiadanacionalciencias > Acesso em: 18 out. 2020. 
2019 exatamente as disciplinas de Física, Química, Biologia e Astronomia, tendo todos os coordenadores estaduais formação em alguma das disciplinas mencionadas. O Ciência é 10 também parece direcionado para as Ciências Naturais, o que pode ser compreensível a partir do seguinte enunciado disponível na página eletrônica da Coordenação de Aperfeiçoamento de Pessoal de Nível Superior (CAPES): "um curso de Especialização em Ensino de Ciências - Anos finais do Ensino Fundamental 'Ciência é 10!', voltado aos professores que ensinam essa disciplina do sexto ao nono ano do ensino fundamental" ${ }^{\prime 15}$ (itálico adicionado).

As chamadas para instituições e para pesquisadores, diferentemente das outras duas ações, trazem informações explícitas de que todas as disciplinas escolares podem ser envolvidas nas propostas a serem apresentadas, conforme observável no Exemplo 1, em que foram reproduzidos dois excertos do edital para pesquisadores, divulgado pelo Conselho Nacional de Desenvolvimento Científico e Tecnológico $(\mathrm{CNPq})^{16}$. Um dos objetivos é incentivar "a integração entre disciplinas".

Exemplo 1 - Chamada MCTIC/CNPq Nº5/2019

1.1 - O objetivo desta chamada é financiar projetos de pesquisa, intervenção e avaliação, nas diversas áreas do conhecimento, em questões relacionadas ao ensino de ciências na educação básica (anos finais do Ensino Fundamental e Ensino Médio) das redes públicas de ensino, no âmbito do Programa Ciência na Escola.

1.1.1 - Os projetos a serem financiados nesta Chamada poderão versar sobre o ensino de qualquer uma das disciplinas que fazem parte do currículo escolar dos anos finais do Ensino Fundamental e do Ensino Médio, devendo privilegiar o letramento científico, o uso de abordagens investigativas e de metodologias ativas de ensino, a aproximação entre as Instituições de Ensino Superior (IES) e as Instituições Científicas, Tecnológicas e de Inovação (ICT) com as escolas públicas, a disseminação dos métodos científicos das diferentes áreas do conhecimento, a integração entre as disciplinas e o despertar da vocação dos alunos e professores da educação básica para as carreiras científicas.

Conforme o edital focalizado, as propostas interventivas a serem implementadas em escolas básicas devem focalizar o "letramento científico", "abordagens investigativas", "metodologias ativas de ensino", além de promoverem "a disseminação dos métodos científicos das diferentes áreas do conhecimento".

15. Fonte: <https://www.capes.gov.br/36-noticias/9443-capes-participa-de-lancamento-do-programaciencia-na-escola $>$ Acesso em: 18 out. 2020.

16. O único projeto aprovado e inserido no campo dos estudos linguísticos foi o "ConGraEduc Conscientização Gramatical pela Educação Científica" (CNPq 441194/2019-2), coordenado pelo autor deste artigo, obtendo a sexta colocação na Linha 2 de financiamento - "Ações de intervenção em escolas de educação básica com foco em ensino de ciências". O recurso financeiro disponibilizado para implementação dos projetos foi reduzido e o repasse total dos valores aprovados continua em atraso até o momento da revisão final deste artigo, após avaliação dos pareceristas. 
Realça-se aqui o propósito de "despertar da vocação dos alunos e professores da educação básica para as carreiras científicas". A vocação dos professores para produzir conhecimento, já anunciada e cobrada por diversos especialistas, a exemplo do que fez o educador brasileiro Paulo Freire, desde a década de 60, no Século XX, ainda se configura como um desafio a ser conquistado ${ }^{17}$. Se bem implementado, esse tipo de política do edital pode contribuir para a legitimação da escola como espaço de produção de conhecimento científico, além de contribuir para ampliar concepções de ciência compartilhadas pela população (SILVA et al, 2018a; 2018b), envolvendo as disciplinas escolares inseridas na grande área das humanidades.

Por razões econômicas diversas, a exemplo da pouca tradição na geração de produtos comercializáveis, as humanidades ocupam posições periféricas dentro e fora do domínio científico. Esse fato foi mostrado na introdução deste artigo, quando foi descrito o contexto histórico desencadeador dos estudos da educação científica, os quais foram atrelados exclusivamente às Ciências Naturais. Como mais uma evidência, menciona-se o estudo sobre políticas de internacionalização universitária realizado por Signorini (2018, p. 218), ao focalizar estratégias desenvolvidas por uma renomada universidade pública brasileira. A autora constatou o lugar periférico atribuído às humanidades, especialmente aos estudos da linguagem, como consequência da "hierarquização orientada por critérios e normas próprias dos ranqueamentos internacionais, tidos como imparciais e objetivos". Ainda nos termos da autora, aos estudos da linguagem, "foi atribuído um papel instrumental ao ensino de gêneros acadêmicos escritos e de línguas estrangeiras" para outras áreas do conhecimento (p. 216).

Os usos da abordagem da educação científica na LA não se restringem a encaminhamentos de propostas pedagógicas, alcança também o trabalho investigativo quando procedimentos de pesquisa são apreendidos como objetos de investigação. A esse respeito menciona-se o estudo apresentado em Silva (2019b), que, para compreender a construção da educação científica de professoras de Português, num programa de mestrado profissional em rede, estudou alguns procedimentos investigativos registrados em dissertações de mestrado apresentadas como trabalho de conclusão do curso. A investigação desses procedimentos permitiu verificar como estavam sendo implementadas as diretrizes de formação continuada do mestrado profissional, além de compreender como as professoras construíram objetos de pesquisa para as próprias dissertações a partir de problemas

17. Segundo Freire (2017, p. 20), "a dodiscência (docência + discência) e a pesquisa são indicotomizáveis". 
ou desafios identificados nas aulas de língua materna. Em outras palavras, a educação científica foi atrelada à autonomia docente para mobilizar procedimentos teóricometodológicos pertinentes às demandas do próprio local de trabalho.

Conforme ilustrado nos excertos do Exemplo 2, o enfoque investigativo esteve na fronteira entre as perspectivas do letramento científico e do letramento do professor ${ }^{18}$. Os resultados revelaram uma sobrevalorização das teorias linguísticas e do próprio produto final gerado nas pesquisas interventivas, mostrando o comprometimento do trabalho de mestrado com o fortalecimento das teorias linguísticas de referência e, conforme excerto subsequente, com a garantia do título desejado. $\mathrm{O}$ enfoque detalhado do processo experienciado pelas professoras, informado por uma reflexão privilegiada sobre a própria prática profissional, por estar orientada por teorias de referência, poderia produzir resultados que realçasse o agir docente.

Exemplo 2: letramento do professor/letramento científico

As pesquisas examinadas aqui parecem comprometidas com o reconhecimento da eficiência das teorias linguísticas, daí a valorização do produto final e não do processo que informa diferentes fases entre a ação e a investigação. (p. 42; itálico do original)

Os MP para educadores precisam ser concebidos a partir das complexas condições de trabalho na escola básica, onde se precisa desenvolver uma formação integral dos jovens aprendizes. Às professoras e aos alunos, não interessa reduzir o ProfLetras ao papel de dispositivo produtor de números para alimentar as estatísticas governamentais. É preciso garantir ganhos efetivos para a formação dos referidos atores sociais, bem como dos formadores vinculados às universidades, que passam a usufruir de experiências profissionais diferenciadas no contato direto com as professoras. (p. 53)

O segundo excerto do Exemplo 2 salienta o risco de a experiência de pesquisa ser reduzida à contabilização de diplomas, com resultados proveitosos para os políticos da situação, haja vista as autopromoções a partir daí produzidas. Salienta ainda o compartilhamento de benefícios gerados diretamente para as professoras da escola básica (como alunas do curso) e para os docentes universitários (formadores). Alerta-se sobre possíveis ganhos para a universidade, uma vez que possibilita a aproximação entre formadores e instituições de ensino básico, numa interação

18. Conforme Kleiman e Borges da Silva (2008, p. 34), o letramento do professor "trata-se de um conjunto de conhecimentos teóricos sobre as diversas disciplinas que se ocupam da matéria objeto de ensino; de conhecimento didático-pedagógicos e socioculturais sobre a comunidade alvo do ensino; de conhecimentos mais subjetivos, advindos de suas experiências profissionais, que resultam em estratégias e procedimentos de ensino e das capacidades de mobilização de textos e outros recursos didáticos a serem usados segundo as condições de trabalho afetivamente encontradas, de acordo com a avaliação que o docente faz do sucesso ou insucesso, para a aprendizagem, do contexto em construção". 
que se espera mais harmoniosa, resultando em troca e produção de saberes ${ }^{19}$. A operacionalização desses encaminhamentos para o mestrado profissional fragiliza a representação de acadêmicos "afastados do mundo real, vivendo em torres de marfim e imersos em teoria pura" (ROBINSON, ARONICA, 2019, p. 19).

Conforme representado na Figura 2, as diferentes perspectivas exemplificadas de estudos do letramento se sobrepõem em algum momento. Não há fronteiras rígidas, o que há são múltiplos letramentos. A delimitação, porém, realça o objeto estudado e, no caso do letramento científico, ressalta-se a motivação política assumida neste artigo. Esse termo permite popularizar e visibilizar as práticas científicas nas humanidades e, mais precisamente, nas ciências linguísticas.

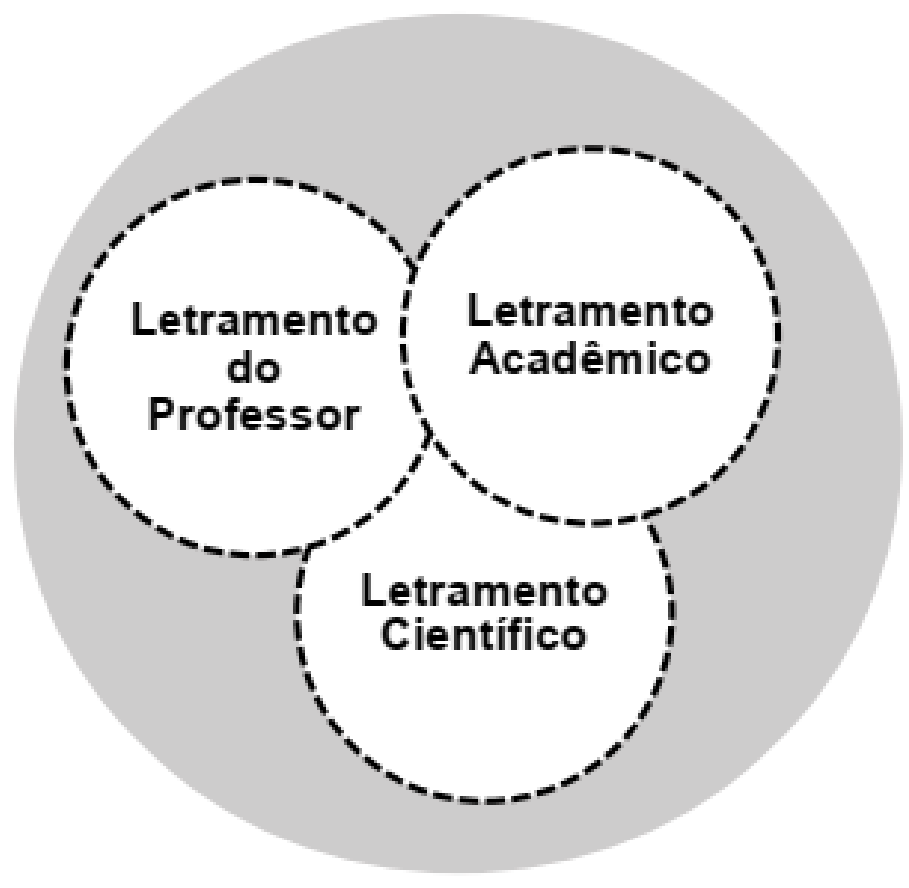

Figura 2. Letramentos

Fonte: autoria própria

19. Concorda-se com Porto (2010, p. 99) ao afirmar que "a formação docente não pode acontecer sem estar de 'braços dados' com a pesquisa no e sobre o cotidiano escolar, local de atuação de profissionais qualificados pela universidade, nutrindo-se dessa prática e fornecendo 'nutrientes' aos profissionais em atuação. Enfatizo que nós, professores universitários, para qualificarmos nosso trabalho, deveríamos estar "com os pés dentro da escola". 
Como outro exemplo da fluidez das fronteiras, menciona-se a pesquisa de Leite, Pereira e Barbosa (2018) que, mesmo utilizando o termo letramento acadêmico, investigam o agir científico de pesquisadores dos estudos literários, apreensível a partir da investigação de artigos científicos por eles produzidos. Como os gêneros são construções sociais semiotizadas em textos, ao investigar a escrita acadêmica, além de se compreender o fazer científico de um dado grupo profissional, identifica-se possíveis forças incidentes sobre as práticas e significados identitários. No Exemplo 3, reproduzimos dois excertos ilustrativos da abordagem do trabalho focalizado.

Exemplo 3: letramento acadêmico/letramento científico

Assim, longe de constituírem [as normas socialmente validadas pelo grupo] um desvio de um pretenso padrão de referência, são o resultado de um processo intencional de adaptação de um gênero e de modos de fazer ciência em função das regras e dos valores que permeiam as atividades e ações linguageiras na disciplina. (p. 946)

A especificidade do campo dos estudos literários, como procuramos demonstrar neste artigo, não está somente no tratamento de um dado objeto de estudo, mas também nos diferentes juízos de valor ou de visões de mundo, ou de ciência e de fazer científico, que permeiam e (con)formam as ações linguageiras que têm lugar na instância acadêmica. (p. 946)

Dados os argumentos expostos previamente, optar-se-ia pelo termo letramento científico para pesquisas do tipo compartilhada por Leite, Pereira e Barbosa (2018). Assim, realçar-se-iam, minimamente, os estudos literários como ciência dentro da vasta área resiliente das humanidades, consideradas legitimamente as especificidades da referida disciplina - Literatura.

$\mathrm{Na}$ seção seguinte, são apresentados os fundamentos teórico-práticos reunidos para sustentar a abordagem da educação científica proposta, os quais podem ser mobilizados, especialmente, em função de práticas de ensino e de pesquisa em torno da formação de professores e do ensino de língua materna.

\section{QUAL É A ABORDAGEM PROPOSTA DE EDUCAÇÃO CIENTÍFICA?}

A abordagem da educação científica proposta está alinhada ao que Rajagopalan (2002) denomina de teorias de resistência, por estarem comprometidas em proporcionar a autonomia necessária para que as pessoas se apropriem de saberes, 
práticas, habilidades ou competências necessárias ao exercício da cidadania ${ }^{20}$. Esse comprometimento encontra-se nas bases das teorias do letramento, que não deveria ser reduzido ao conhecimento ou habilidade para realizar qualquer coisa, conforme acontece frequentemente em contextos pedagógicos, escapando-se os usos ou mediações pela escrita.

A abordagem defendida não se propõe ao endosso da sobrevalorização de conhecimentos e práticas científicas existente na sociedade. Essa atitude diante dos produtos científicos é incisivamente criticada nos escritos freirianos, quando se recomenda que os especialistas se dispunham ao diálogo junto ao cidadão comum, a exemplo do agrônomo com o camponês e do professor com os alunos (FREIRE, 1977; FREIRE; FAUNDEZ, 2017) ${ }^{21}$. Com culturas, crenças e saberes desprestigiados, o cidadão comum fica sujeito à exclusão, fracassa em interações características de contextos escolares e não escolares, inclusive nos próprios componentes curriculares.

É reproduzido adiante um excerto sintetizador do tipo de assimetria instaurada diante dos saberes especializados, bem como o posicionamento defendido numa perspectiva freiriana. Trata-se de um recorte de uma resposta de Antonio Faundez, educador chileno, em diálogo com Paulo Freire (FREIRE; FAUNDEZ, 2017, p. 83-84).

O saber científico, considerado por todos nós como o Saber, leva-nos a considerá-lo um saber em nós mesmos. Ele nos torna poderosos e, como tal, autoritários. Através dessa concepção do saber como poder, vemos claramente como a estrutura social pode ser explicada a partir de lutas pelo poder, de poderes distintos, em que uma parte desse poder ou desses poderes que aparecem na sociedade corresponderia ao intelectual, pelo fato de que ele detém o saber científico. Esse intelectual menospreza o saber que não é científico e, inconscientemente, o saber popular; para o intelectual e político, o senso comum popular mostra-se como um não saber e, enquanto não saber, como um não poder.

$\mathrm{Na}$ medida em que as massas não detêm o saber que o intelectual possui, elas não detêm o poder. E esse desprezo pelo saber popular afasta o intelectual das massas. Creio que uma das coisas que o intelectual deve aceitar é que esse saber popular é de uma riqueza sociológica fundamental para qualquer ato político, para qualquer ato de transformação da sociedade.

No meu entender, a primeira coisa que um intelectual progressista deve fazer, se quer juntarse às massas, é respeitar esse saber e procurar apropriar-se dele. Meter-se nesse saber é, como você dizia, apropriar-se do sentimento, deste sentir, deste atuar das massas, que se

20. Conforme Perrenoud (2005, p. 32-33), "a aprendizagem da cidadania passa pela adesão a valores e à lei, pela reflexão sobre o que seria uma organização ideal da comunidade, mas sobretudo pelo conhecimento realista dos mecanismos demográficos, econômicos, políticos, psicossociológicos ou jurídicos em ação, que sempre frustram nossos ideais".

21. Ressalta-se que a valorização de saberes do senso comum não pressupõe negação da ciência. Essa negação é denominada por Paulo Freire de basismo. Segundo o autor, "nem elitismo nem basismo. Um não é contrário positivo do outro. [...] A minha posição é a da comunhão entre o senso comum e a rigorosidade" (FREIRE; FAUNDEZ, 2017, p. 87). 
manifesta fundamentalmente através da resistência ou das expressões culturais de resistência. Esta apropriação poderá, então, permitir ao intelectual propor seu saber "científico" recebendo, por sua vez, a sensibilidade das massas. E as massas poderiam apropriar-se desse saber científico, não da maneira como é formulado pelo intelectual, mas transformando-o. O saber "científico" transforma-se em científico apenas à medida que ele se apropria do saber popular. E o saber popular se transforma num saber de ação e transformação eficaz quando se apropria, por sua vez, de forma criativa, deste saber "científico" proposto pelo intelectual (itálico adicionado).

A prática de transmissão de saberes ou técnicas por especialistas, em substituição à cultura local, desprovida de um consistente conhecimento das necessidades e dinâmicas do grupo, é denominada extensão por Freire (1977). Tratase de um trabalho que o pesquisador ou professor desenvolve sobre e não com os sujeitos, agora, participantes ou colaboradores. Em oposição, o autor propõe a prática da comunicação, caracterizada pela escuta sensível do cidadão comum por parte do especialista disponível a trocas, negociações e construções conjuntas de saberes.

A comunicação é esperada na interação entre professores e alunos em situações educativas informadas pela abordagem defendida neste artigo. Assim, compreende-se que "a educação é comunicação, é diálogo, na medida em que não é a transferência de saber, mas um encontro de sujeitos interlocutores que buscam a significação dos significados" (FREIRE, 1977, p. 69). Na Figura 3, foram reunidas algumas escolhas lexicais realizadas por Freire (1977) para caracterizar as referidas práticas contrapostas.

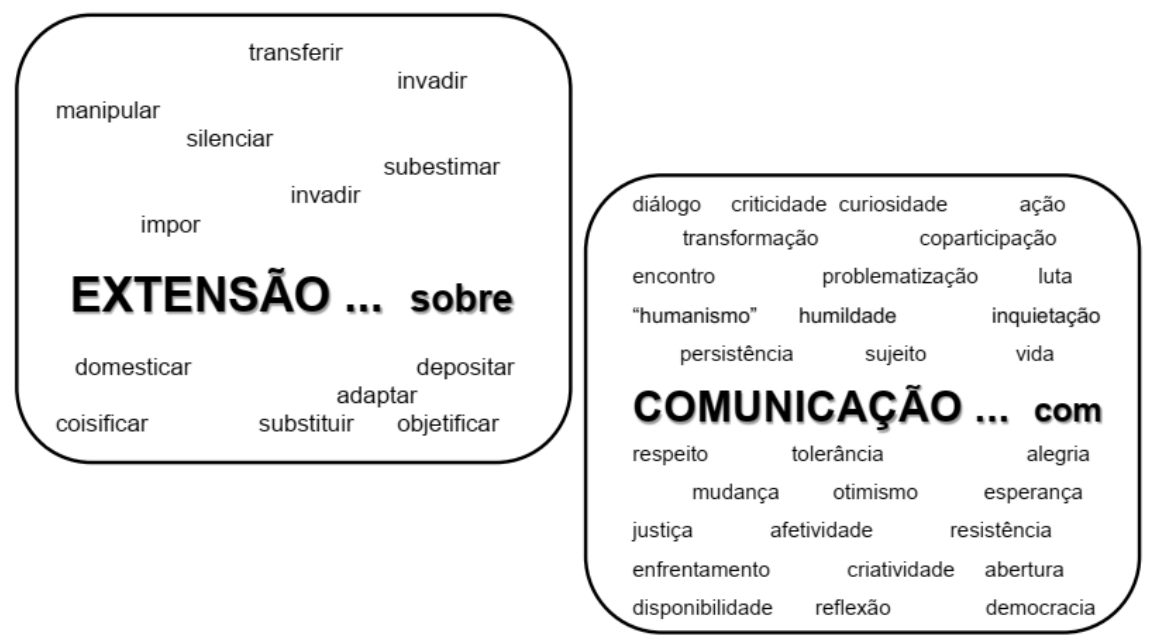

Figura 3. Extensão e Comunicação

Fonte: produzida a partir de Freire (1977) 
A título de ilustração da relevância de saberes locais menosprezados por especialistas interessados em ganhos econômicos imediatos (mesmo custando prejuízos inestimáveis à natureza e, consequentemente, à sobrevivência humana), salienta-se a estreita relação dos indígenas com a natureza/terra, compreendida como "mãe e provedora em amplos sentidos, não só na dimensão da subsistência e na manutenção das nossas vidas, mas também na dimensão transcendente" responsável pela existência indígena (KRENAK, 2019, p. 43). Negando a percepção dos rios como recursos, Krenak (2019, p. 49) esclarece que eles são pessoas, assim como as montanhas, pois, mantendo-se tal relação, os indígenas evitam que esses lugares sejam tomados como "resíduos da atividade industrial e extrativista". Essa estreita relação exemplifica a "riqueza sociológica fundamental [do saber popular] para qualquer ato político, para qualquer ato de transformação da sociedade", de que falou Antonio Faundez (FREIRE; FAUNDEZ, 2017, p. 84)

Alinhada à prática comunicativa, menciona-se ainda a proposta de pesquisaensino defendida por Penteado (2010) na Ciência da Educação. Essa pesquisa rearranja posicionamentos tradicionalmente ocupados por escolas e universidade, sendo estas últimas o locus privilegiado de produção do conhecimento legitimado, ao passo que às primeiras é reservada a função de consumidoras de saberes. Contrapondo-se a essa dinâmica, a pesquisa-ensino se caracteriza como uma investigação realizada a partir da parceria entre professor da escola básica, que tem uma demanda no próprio local de trabalho a ser resolvida, e o docente do ensino superior, que assume a pesquisa como uma prática revigoradora da função de formador.

Esses profissionais são denominados, respectivamente, de professor-pesquisador e pesquisador-professor. O exercício dessas funções também pode ser produtivo no contexto de formação inicial (prioritariamente nos estágios supervisionados obrigatórios) e continuada de professores, especialmente quando se pretende familiarizar os professores com a abordagem da educação científica. A Figura 4 sintetiza a compreensão de Penteado (2010) sobre a pesquisa-ensino. Destaca-se aqui a necessidade de o formador também investigar a própria prática profissional a fim de aprimorá-la, atitude não exclusiva do professor da escola básica. 


\section{PROFESSOR-PESQUISADOR}

"é aquele que, ao ensinar, pesquisa o seu ensino; toma conhecimento sobre o ensino e sobre a prática docente como cerne do ofício [...] inclui a docência como uma das variáveis a ser considerada, problematizada, transformada".

\section{PESQUISADOR-PROFESSOR}

"é o acadêmico que pesquisa e ensina a pesquisar, tendo na pesquisa o cerne de seu ofício. Encontram-se umbilicalmente reunidos na e pela realização da pesquisa-ensino, da qual depende 0 produto de seus trabalhos".

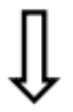

INTENCIONALIDADE

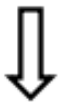

\section{"promover uma intervenção transformadora em sua prática docente que venha a resolver o problema que encaminhou sua ação de pesquisa".}

"contribuir com a construção de teoria da docência, ou do ensino, pelo acesso compreensivo e científico às características de uma prática docente que não é a sua".

\section{Figura 4. Pesquisa-Ensino}

Fonte: produzida a partir de Penteado (2010, p. 39)

A prática da comunicação se configura como uma resposta às pedagogias reprodutivistas, denominadas de enciclopedismo por Perrenoud (2005) e de padronização por Robinson e Aronica (2019). Essas se mostram improdutivas para responder às demandas contemporâneas de formação, onde a autonomia, criatividade e inovação tornaram-se atitudes e estratégia de sucesso. Em outras palavras, as escolas precisam proporcionar a formação de pessoas capazes de solucionar problemas emergentes e não simplesmente reproduzirem alguns saberes. Brown (2009), por exemplo, afirma que, no mundo dos negócios, houve uma evolução natural do design doing para o design thinking, ou seja, as demandas pela criação de produtos físicos cederam lugar às demandas pelo planejamento de processos, bens de serviços ${ }^{22}$. Ainda nas palavras do autor,

O centro da atividade econômica no mundo em desenvolvimento muda inexoravelmente da manufatura industrial para a criação de conhecimento e a prestação de serviços. Além disso, não se limita mais à introdução de novos produtos físicos, mas inclui novos tipos de processos, serviços, interações, formas de entretenimento e formas de comunicação e colaboração (BROWN, 2009, p. 13-14).

22. Conforme Brown (2009, p. 209), "o surgimento do design thinking corresponde a uma mudança de cultura, e o que excita os melhores pensadores hoje em dia é o desafio de aplicar suas habilidades a problemas importantes. Melhorar a vida das pessoas em extrema necessidade está perto do topo dessa lista". 
A metodologia do Design Thinking reúne competências demandadas das pessoas na contemporaneidade. A eficiência está na qualidade das experiências dos usuários com o produto entregue e não no volume da produção. Hoje, não basta que as pessoas funcionem como consumidoras, mas é necessário que participem da produção de artefatos e serviços. Brown (2009) menciona o uso dessa estratégia de pensamento por escolas para evitar a erradicação da "inclinação natural das crianças para experimentar e criar", deseja-se, diferentemente, incentivá-la e amplificar tais inclinações. A relevância da educação científica para estimular a criatividade das crianças pode ser observada nas palavras de Brown (2009, p. 229) ao afirmar que, "como sociedade, nossa capacidade futura de inovação depende de altos níveis de letramento em matemática e ciências". À asserção do autor, acrescenta-se aqui o letramento linguístico, compreendido como habilidades de trabalho (in)consciente sobre a língua(gem) em função de propósitos interacionais (HALLIDAY, 1996; HASAN, 1996).

$\mathrm{Na}$ Figura 5, são reproduzidas as etapas constitutivas do processo de implementação do Design Thinking, as quais são aqui sinteticamente descritas a fim de se estabelecer um paralelo com as competências passíveis de desenvolvimento nos alunos a partir da abordagem pedagógica da educação científica. Em outras palavras, transitar pelo Design Thinking demanda competências, que também poderão ser desencadeadas ou fortalecidas na escola. Trata-se de um trabalho em equipes multidisciplinares, envolvendo a participação de cidadãos comuns engajados com a situação focalizada ou de especialistas de diferentes áreas que possam contribuir com olhares diferenciados sobre o problema apresentado.

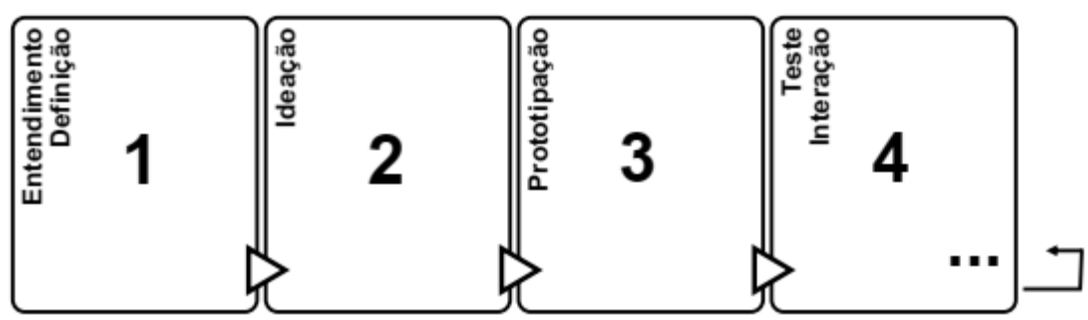

Figura 5. etapas do design thinking

Fonte: produzida a partir de Brown (2009)

Inicialmente, para produzir soluções, os Designers precisam compreender profundamente o problema apresentado, pois, por vezes, nem o próprio demandante do serviço, consegue defini-lo. São utilizadas diferentes metodologias de pesquisa para interagir com pessoas inseridas no contexto investigado, necessitando, 
portanto, da empatia por parte dos pesquisadores, os problemas precisam ser compreendidos do ponto de vista dos usuários. Os dados gerados são interpretados e literaturas podem ser acessadas para apreender a complexidade do problema. $\mathrm{Na}$ ideação, considerando os dados gerados previamente, são realizados brainstorms, mapas mentais e simulação de situações para gerar prováveis soluções para o problema. $\mathrm{Na}$ prototipação, são produzidos protótipos para serem posteriormente avaliados pelos próprios usuários na etapa final, denominada teste/interação. A depender da reação do usuário ao produto entregue, etapas anteriores podem ser retomadas.

Ao insistir com argumentos atrelados a setores econômicos, não se defende aqui que a escola possua como objetivo exclusivo a preparação dos alunos para o mundo do trabalho. Porém a dinâmica econômica fala sobre as demandas e transformações pelas quais passa a sociedade da qual os alunos fazem parte. Tal objetivo, talvez, seja alcançado como consequência de inúmeras competências a serem garantidas para os aprendizes. Assim, concorda-se com Perrenoud (2005, p. 71) ao afirmar que

O desafio da escola obrigatória são as competências que fazem de nós não apenas trabalhadores, independentes ou assalariados, mas seres autônomos, cidadãos responsáveis, pessoas que têm uma vida privada, familiar, espiritual, sexual, associativa, de lazer, de engajamento em diversos projetos e em diversas causas. Essa reflexão não é apenas técnica; ela coloca, antes de tudo, a questão das finalidades da escola. É urgente reconstruir uma transposição didática com base em sondagens sérias a respeito do que as pessoas precisam efetivamente para viver, refletir, formar-se e atuar em todos esses registros.

Em aulas de língua materna, a abordagem pedagógica da educação científica pode proporcionar mudanças substanciais nas aulas planejadas, compartilhandose o espaço dos objetos de conhecimento (ou conteúdos disciplinares) com competências a serem desenvolvidas nos alunos. Nos termos de Perrenoud (2005, p. 73), "não se trata de abrir mão de ensinar os conhecimentos disciplinares, mas de fazer com que eles contribuam para as competências que, até certo ponto, os transcendem". Espera-se ainda que as situações interativas instauradas a partir de projetos de letramento científico garantam a familiarização dos alunos com uma diversidade de práticas sociais ${ }^{23}$.

$\mathrm{Na}$ Figura 6, são elencados sete princípios interconectados a serem trabalhados para garantir diretamente a educação científica dos alunos, esses princípios podem ser focalizados em quaisquer componentes curriculares ${ }^{24}$. Para realçar a importância da referida abordagem na formação discente, os referidos princípios

23. Como exemplos de projetos de letramento científico, sugere-se a leitura de Fidelis (2018), Mendes (2018), Reis (2016) e Ribeiro (2018).

24. Uma versão preliminar dos princípios da educação científica fora proposta sob a denominação de princípios do letramento científico por Sousa (2016). 
foram justapostos às principais competências a serem garantidas na formação dos aprendizes ${ }^{25}$, conforme seleção apresentada por Robinson e Aronica (2019) e compartilhada na Figura 7. Indiretamente, espera-se que as oito competências formativas desenvolvidas também auxiliem as pessoas em interações instauradas em outros domínios sociais.

Figura 6: Princípios

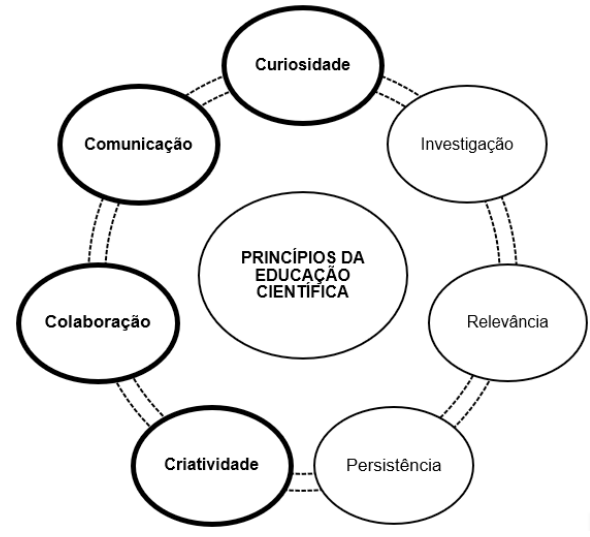

Fonte: adaptado de Sousa (2016)
Figura 7: Competências

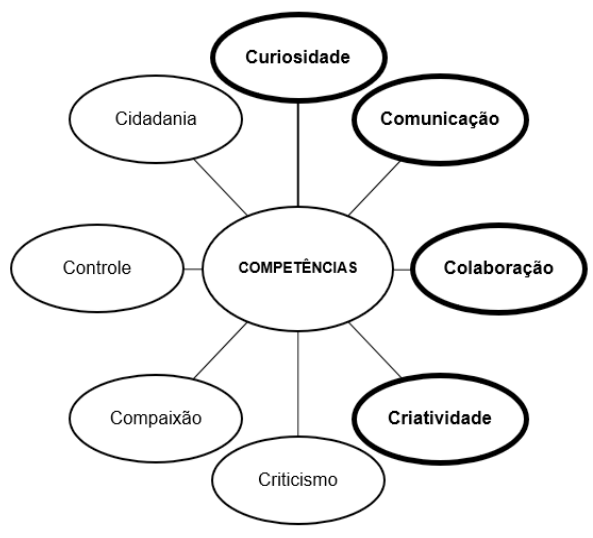

Fonte: produzido a partir de Robinson e Aronica (2019)

Dos sete princípios elencados, quatro (curiosidade, comunicação, colaboração, criatividade) correspondem diretamente a competências elencadas, conforme destaque com balões negritados nas figuras. Os outros três princípios colaboram para o desenvolvimento do conjunto das oito competências.

A curiosidade se configura como o ponto de partida para se ter o que pesquisar e deve ser incentivada pela escola. Robinson e Aronica (2019, p. 3) afirmam que a curiosidade é um "apetite [que] começa a desaparecer quando [as crianças] entram na escola. Mantê-lo vivo é o segredo para transformar a educação". A curiosidade provoca perguntas que podem ser respondidas a partir da pesquisa. Os alunos precisam ser sensibilizados para elaborar perguntas sobre a língua(gem) em contextos situados, pois, comumente, os componentes de ensino de língua não

25. As competências elencadas por Robinson e Aronica (2019) alinham-se às competências gerais $\mathrm{e}$, consequentemente, às especificas para aulas de Língua Portuguesa no Ensino Fundamental e Ensino Médio, apresentadas na Base Nacional Comum Curricular - BNCC (BRASIL, 2019), documento orientador do currículo mínimo a ser implementado em escolas brasileiras. Um estudo do espaço garantido à educação científica na BNCC (BRASIL, 2019) será compartilhado em publicação futura. 
são compreendidos como possíveis espaços de investigação científica sobre objetos linguísticos, mas, sim, como coadjuvantes diante da demanda por textos escritos a serem produzidos em outros componentes curriculares (FERNANDES, 2016). Antonio Faundez afirma, em diálogo com Paulo Freire, que "todo conhecimento começa pela pergunta" e, mais, "a curiosidade é uma pergunta" (FREIRE; FAUNDEZ, 2017, p. 67).

A comunicação foi elencada como um princípio em duplo sentido interconectado. O primeiro está alinhado à concepção de interação democrática proposta por Freire (1977), envolve empatia, respeito e tolerância diante da diversidade cultural trazida por colaboradores ou participantes da pesquisa. Assim, pode-se afirmar que a comunicação demanda diretamente a competência de compaixão. $\mathrm{O}$ segundo sentido corresponde à familiarização dos alunos com eventos de letramento científico, relaciona-se ao desenvolvimento de habilidades para se utilizar de mecanismos linguísticos das interações características das atividades científicas.

A colaboração é extremamente importante para o aprendizado das pessoas, envolvendo formas de convivência e do trabalho em equipe, habilidades necessárias ao desenvolvimento do design thinking. Atrela-se diretamente à competência de controle, quando se espera uma harmonia da pessoa com ela mesma e na convivência com outros. As trocas de experiências e conhecimentos entre pessoas diversas (especialistas ou não) possibilitam a criação ou adaptação de produtos, ideias ou processos em resposta a demandas existentes; geram alguma inovação, "compreendida como deslocamento ou reconfiguração dos modos rotineiros de raciocinar/agir/avaliar" (SIGNORINI, 2007b, p. 9) ${ }^{26}$. A inovação também se configura como um ato de resistência diante de inquietações provocadas por riscos ou incômodos. Esse trabalho também é resultado da criatividade, potencializada pela negociação compromissada com o pensamento colaborativo e criativo, conforme esclarecido por Brown (2009).

26. Signorini (2007b, p. 9) esclarece ainda que "a inovação é aqui compreendida como uma categoria de base interpretativa, portanto não-universal e muito menos transparente ou neutra: inovador é sempre uma qualificação positiva que favorece determinados agentes sociais em detrimento de outros, o que faz com que esteja sempre sujeita a contestação. Valem-se dela os agentes sociais, individuais e coletivos, para dar conta das contínuas demandas de adaptação e transformação de seus próprios contextos de atuação. Assim, a ideia de inovação vai estar sempre associada à de mudança e, quase sempre, à de modernização, progresso ou desenvolvimento numa dada direção. Todavia, como as demandas de mudança nem sempre são localmente controláveis e podem estar em relação de confronto com outras no mesmo contexto, a inovação pode também estar associada a mecanismos de resistências à mudança, ou de resistências à mudança numa dada direção (inovar para manter o status quo, por exemplo). Nesse caso, torna-se polêmica a relação entre inovação e mudanças (inovar para não mudar), particularmente entre inovação e progresso ou desenvolvimento". 
A investigação corresponde ao procedimento necessário para se elaborar resposta à curiosidade. Para garantir que a investigação se desdobre em ação, devese considerar a relevância do problema embutido na curiosidade. Pode ser relacionada às relevâncias elencadas por Van Aalsvoort (2004a; 2004b), descritas na segunda seção deste artigo. Foram identificadas para serem observadas em aulas de Química, escapando-se do ensino reprodutivo: pessoal; profissional; social; pessoal/social. Pode-se ainda atrelar tal relevância aos critérios elencados por Brown (2009) para se produzir ideias promissoras ou sustentáveis: desejabilidade, factibilidade e viabilidade.

A persistência corresponde a um atributo demandado do pesquisador por ser a investigação científica uma atividade trabalhosa, que requer bastante dedicação dos participantes. Ao desenvolver esse princípio, os alunos poderão mobilizá-lo em outras circunstâncias ao longo da vida, evitando a desistência ou o abandono de metas diante de possibilidades de esmorecimento. Em investigações científicas, tem-se clareza do ponto de partida, sendo o percurso e o ponto de chegada imprecisos, assim, faz-se necessários persistir e resistir.

Finalmente, destaca-se que a cidadania, talvez, seja a mais valorosa das competências, ao mesmo tempo em que parece depender de todas as demais. O exercício da cidadania demanda a observância de deveres social $/ \mathrm{moral} /$ legalmente postos e o usufruto de direitos, por vezes, cerceados em sociedades mantenedoras de desigualdades. A resistência é um exercício de cidadania, caracteriza-se por formas de ação em defesa de direitos individuais e coletivos, ameaçados ou, até mesmo, usurpados. Propõe-se, portanto, uma abordagem diferenciada da educação científica por se acreditar, compartilhando sonhos e esperanças sustentadas por inúmeros professores e formadores, que as aulas de língua materna sejam espaços de resistência.

\section{CONSIDERAÇÕES FINAIS}

Neste estudo, foi realizada uma releitura da abordagem da educação científica, com propósito de adequá-la a práticas de pesquisa nos estudos linguísticos aplicados e de ensino e formação de professores de língua materna. A releitura foi ancorada em estudos do letramento e reforçou a necessidade de readequações funcionais de elementos integrantes de práticas de pesquisa e de ensino informadas por paradigmas da tradição. Assim, garantem-se investigações mais democráticas e culturalmente sensíveis e uma abordagem pedagógica crítica, evitando o ensino reprodutivo, padronizado ou enciclopédico característico da tradição escolar. 
As readequações resultaram da seleção de aspectos caracterizadores de diferentes propostas críticas revisadas, dentre as quais destacam-se: (a) diálogo entre especialistas de diferentes áreas do conhecimento e cidadãos comuns (inclusive representantes de coletivos); (b) valorização de saberes de origens diversas, a exemplo dos produzidos em universidades, escolas e coletivos; e (c) fluidez de papéis assumidos em interações entre professores e formadores, envolvendo trocas de saberes e experiências para fortalecimento mútuo, e professores e alunos, envolvendo revisão, adaptação ou criação de saberes, produtos ou processos, cooperativamente.

Finalmente, destaca-se que a abordagem da educação científica se configura como uma estratégia de resistência, permitindo o enfrentamento da (i) hegemonia das ciências naturais no imaginário popular, possibilitando que as pessoas também reconheçam pesquisas, contribuições, práticas e demandas em torno das humanidades, especialmente dos estudos linguísticos; e de (ii) políticas de fragilização das ciências, a exemplo da concessão de investimentos inexpressíveis para pesquisas. Para tais enfretamentos, faz-se necessária a educação científica da população, tornando-a uma aliada esclarecida da comunidade acadêmica.

\section{REFERÊNCIAS}

BRASIL. (2018). Base Nacional Comum Curricular. Brasília: MEC. Fonte: http:// basenacionalcomum.mec.gov.br/. Acesso em: 12 set. 2020.

BROWN, T. (2009). Change by Design: New York: Harper Business.

CHASSOT, A. (2014). Alfabetização científica: questões e desafios para a educação. 6. ed. Ijuí: Editora Unijuí.

DEMO, P. (2010). Educação e alfabetização científica. Campinas: Papirus.

FERNANDES, E. R. (2016). Letramento científico no ensino básico público no município de Palmas - Tocantins. Dissertação de Mestrado em Letras: Ensino de Língua e Literatura. Universidade Federal do Tocantins, Araguaína.

FIDELIS, A. C. (2018). Proposta de ressignificação de práticas escolares de linguagem pela abordagem do letramento científico no ciclo de alfabetização. Dissertação de Mestrado Profissional em Letras - ProfLetras. Universidade Federal do Tocantins, Araguaína.

FREIRE, P. (1977). Extensão on comunicação. 11. ed. Rio de Janeiro: Paz e Terra. 
FREIRE, P. (2011). A importância do ato de ler: em três artigos que se completam. 51. ed. São Paulo: Cortez.

FREIRE, P. (2017). Pedagogia da autonomia: saberes necessários à prática educativa. 55. ed. Rio de Janeiro: Paz \& Terra.

FREIRE, P.; FAUNDEZ, A. (2017). Por uma pedagogia da pergunta. Rio de Janeiro: Paz e Terra.

HALLIDAY, M. A. K. (1996). Literacy and Linguistics: A Functional Perspective. In: HASAN, R.; WILLIAMS, G. (ed.), Literacy in Society. London: Longman, p. 339-376.

HASAN, R. (1996). Literacy, everyday talk and society. In: HASAN, R.; WILLIAMS, G. (ed.), Literacy in Society. London: Longman, p. 377-424.

HOLBROOK, J.; RANNIKMAE, M. (2009). The Meaning of Scientific Literacy. International Journal of Environmental \& Science Education, v. 4, n. 3, p. 275-288.

HURD, P. D. (1958). Science Literacy for American Schools. Educational Leadership. n. 16, p. 13-16.

HURD, P. D. (1998). Scientific Literacy: New Minds for a Changing World. Science Education, v. 82, n. 3, p. 407-416.

KLEIMAN, A. B. (1995). Modelos de letramento e práticas de alfabetização na escola. In: KLEIMAN, A. B. (org.), Os significados do letramento: uma nova perspectiva sobre a prática social da escrita. Campinas: Mercado de Letras, p. 15-61.

KLEIMAN A.; BORGES DA SILVA, S. B. (2008). Letramento no local de trabalho: o professor e seus conhecimentos. In: OLIVEIRA, M. S.; KLEIMAN, A. B. (org.), Letramentos múltiplos: agentes, práticas, representações. Natal: EDUFRN, p. 17-40.

KRENAK, A. (2019). Ideias para adiar o fim do mundo. São Paulo: Companhia das Letras.

LEITE, E. G.; PEREIRA, R. C. M.; BARBOSA, M. S. M. F. (2018). O fazer científico nos estudos literários: das práticas letradas acadêmicas às características epistemológicas. Revista Brasileira de Linguística Aplicada. Belo Horizonte: UFMG, v. 18, n. 4, p. 919-950.

LIU, X. (2009). Beyond Science Literacy: Science and the Public. International Journal of Environmental \& Science Education. v. 4, n. 3, p. 301-311. 
MENDES, J. (2018). Letramento científico a partir de textos propagandísticos em aulas de Língua Portuguesa no ensino fundamental. Dissertação de Mestrado Profissional em Letras - ProfLetras. Universidade Federal do Tocantins, Araguaína.

NASCIMENTO, M. (1998). A alfabetização como objeto de estudo: uma perspectiva processual. In: ROJO, R. (org.), Alfabetização e letramento: perspectivas linguísticas. Campinas: Mercado de Letras, p. 13-59.

PENTEADO, H. D. (2010). Pesquisa-ensino uma modalidade de pesquisa-ação. In: PENTEADO, H. D.; GARRIDO, E. (org.), Pesquisa-ensino: a comunicação escolar na formação do professor. São Paulo: Paulinas, p. 33-44.

PERRENOUND, P. (2005). Escola e cidadania: o papel da escola na formação para a democracia. Porto Alegre: Artmed, 184p.

PORTO, T. M. E. (2010). Pesquisa-ensino: relação universidade/escola e articulação teoria/ prática. In: PENTEADO, H. D.; GARRIDO, E. (org.), Pesquisa-ensino: a comunicação escolar na formação do professor. São Paulo: Paulinas, p. 95-104.

RAJAGOPALAN, K. (2002). Teorizando a resistência. In: SILVA, D. E. G.; VIEIRA, J. A. (org.), Análise do discurso: percursos teóricos e metodológicos. Brasília: Oficina Editorial do Instituto de Letras; Editora Plano, p. 203-219.

REIS, A. P. (2016). Letramento científico como prática inovadora numa escola pública araguainense. Dissertação de Mestrado Profissional em Letras - ProfLetras. Universidade Federal do Tocantins, Araguaína.

RIBEIRO, M. H. C. (2018). Contribuições do letramento científico para o trabalbo pedagógico cooperativo entre as disciplinas de Português e Geografia. Dissertação de Mestrado Profissional em Letras - ProfLetras. Universidade Federal do Tocantins, Araguaína.

ROBINSON, K; ARONICA, L. (2019). Escolas criativas: a revolução que está transformando a educação. Porto Alegre: Penso.

SANTANA, B. R. (2019). Modos de propagação da educação científica na infância: do desenbo animado às práticas escolares. Dissertação de Mestrado em Letras. Universidade Federal do Tocantins, Porto Nacional.

SANTOS, W. L. P. (2007). Educação científica na perspectiva de letramento como prática social: funções, princípios e desafios. Revista Brasileira de Educação. v. 12, n. 36, p. 474-550. 
SASSERON, L. H.; CARVALHO, A. M. P. (2008). Almejando a alfabetização científica no ensino fundamental: a proposição e a procura de indicadores do processo. Investigações em Ensino de Ciências, v. 13, n. 3, p. 333-352.

SIGNORINI, I. (2007a). Letramento escolar e formação do professor de Língua Portuguesa. In: KLEIMAN, A. B.; CAVALCANTI, M. C. (org.), Linguística Aplicada: suas faces e interfaces. Campinas: Mercado de Letras, p. 317-337.

SIGNORINI, I. (2007b). Apresentação. In: SIGNORINI, I. (org.), Significados da inovação no ensino de língua portuguesa e na formação de professores. Campinas: Mercado de Letras, p. $7-15$.

SIGNORINI, I. (2018). Legitimação de políticas científicas locais em função de demandas de internacionalização da universidade. Cadernos Cedes, v. 38, n. 105, p. 205-221.

SILVA, W. R. (2019a). Polêmica da alfabetização no Brasil de Paulo Freire. Trabalhos em Linguística Aplicada. Campinas: Unicamp, v. 58, n. 1, p. 219-240.

SILVA, W. R. (2019b). Construção de práticas de pesquisa no Mestrado Profissional em Letras. In: SILVA, W. R.; BEDRAN, P. F.; BARBOSA, S. A. (org.). Formação de professores de língua na pós-graduação. Campinas: Pontes, p. 25-57.

SILVA, W. R.; CORDEIRO, M. R.; FARAH, B. F.; MORAIS, C. W. R.; SOUSA, D. L.; SILVA, L. L. S.; MENDES, V. C. B. B. (2018A). Ciências nas licenciaturas? Linguagem: Estudos e Pesquisa. Catalão: UFG, v. 22, n. 1, p. 83-108.

SILVA, W. R; MARTINS, R. G.; REIS, A. P.; SANTANA, B. R.; SILVEIRA, R. A.; SANTOS, E. M.; SOUSA, M. S. C.; SANTOS, F. C. (2018b). Compreensão de ciências por professores em formação inicial. Raído. Dourados: UFGD, v. 12, n. 30, p. $35-53$.

SOARES, M. (2003). Letramento e escolarização. RIBEIRO, V. M. (Org.), Letramento no Brasil. São Paulo: Global, p. 89-113.

SOARES, M. (2004). Letramento e alfabetização: as muitas facetas. Revista Brasileira de Educação. v. s/v, n. 25, p. 05-17.

SOUSA, B. S. (2016). Letramento científico a partir de relatórios de pesquisa no Ensino Fundamental II: uma intervenção pedagógica. Dissertação de Mestrado Profissional em Letras. Universidade Federal do Tocantins, Araguaína. 
STREET, J. C.; STREET, B. V. (1991). The Schooling of Literacy. In: BARTON, D.; IVANIC, R. (ed.), Writing in the Community. London: Sage Publications, p. 143-166.

Recebido: $18 / 10 / 2020$

Aceito: 6/11/2020

Publicado: 11/11/2020 